https://cssr.uitm.edu.my/2018/

5th International Conference on Science and Social Research

Le Meridien Kota Kinabalu Hotel, 5 - 6 December 2018

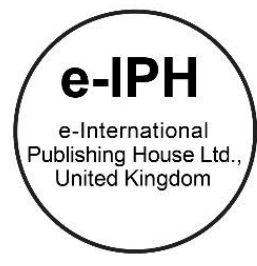

\title{
Exploring Spatial Visualization and Gender Among the 3D Computer Animation Undergraduates
}

\author{
Sharkawi Che Din, Nurul Akma Abdul Wahab, Farhanah Abu Sujak \\ Department of Graphic Design, Faculty of Art \& Design, \\ Universiti Teknologi MARA, 42300 Puncak Alam, Malaysia. \\ sharkawi237@uitm.edu.my, nurulakma_wahab@uitm.edu.my, farha717@uitm.edu.my \\ Tel: $012-2254730$
}

\begin{abstract}
The Deficits in Spatial Visualization may affect the performance of 3D Computer Animation among Multimedia undergraduates. Spatial Visualization can be observed as a unique type of intelligence distinguishable from other forms of intelligence, such as verbal ability and reasoning ability. Most students experienced difficulties in performing the complicated visualization task for creating 3D animation. Students whose spatial visualization skills are insufficient to complete the assignment will not be able to obtain good grades in the 3D computer animation course. The purpose of this research is to explore the relationship between Spatial Visualization, gender, and 3D Computer Animation performance amongst undergraduates.
\end{abstract}

Keywords: Computer Animation; Spatial Visualization; Multimedia;

eISSN: 2398-4287C 2020. The Authors. Published for AMER ABRA cE-Bsby e-International Publishing House, Ltd., UK. This is an open access article under the CC BYNC-ND license (http://creativecommons.org/licenses/by-nc-nd/4.0/). Peer-review under responsibility of AMER (Association of Malaysian Environment-Behaviour Researchers), ABRA (Association of Behavioural Researchers on Asians) and cE-Bs (Centre for Environment-Behaviour Studies), Faculty of Architecture, Planning \& Surveying, Universiti Teknologi MARA, Malaysia. DOI: https://doi.org/10.21834/ebpj.v5iSI3.2537

\subsection{Introduction}

The development of the animation industry in Malaysia provides many career opportunities for 3D animators, which led to recruiters being more selective in recruiting, and gender has also become a factor to hire. This study discusses the spatial visualization, paying attention to the competency of students enrolled in multimedia courses. Here, it explores the literature explicitly about the possible relationship between spatial visualization and 3D computer animation performance among male and female students. This research will also discuss the study of demographic data where gender also plays a vital role in determining the performance of the students. It further looks at reasons on career opportunities for 3D animators in Malaysia who are mostly dominated by males. This article will be divided into two sections where section $\mathrm{A}$ discusses the spatial visualization among multimedia undergraduates, and section B will discuss in-depth about spatial visualization with demographic (gender) in the 3D computer animation.

\subsection{The Art of Visualizations}

eISSN: 2398-4287@ 2020. The Authors. Published for AMER ABRA cE-Bsby e-International Publishing House, Ltd., UK. This is an open access article under the CC BYNC-ND license (http://creativecommons.org/licenses/by-nc-nd/4.0). Peer-review under responsibility of AMER (Association of Malaysian Environment-Behaviour Researchers), ABRA (Association of Behavioural Researchers on Asians) and cE-Bs (Centre for Environment-Behaviour Studies), Faculty of Architecture, Planning \& Surveying, Universiti Teknologi MARA, Malaysia.

DOI: https://doi.org/10.21834/ebpj.v5iSI3.2537 
The issue of spatial visualization is vital in this research, primarily due to the differences in performance amongst multimedia students in many creative multimedia programs, based on their demographics, specifically in terms of gender. A research by Kamis et al., (2016) discussed that apparel design students also need spatial ability as an essential aspect in their career. Besides, Strong and Smith (2002) added that spatial ability is the ability to detect and describe the form, space, color, and line, including the ability to present ideas visually and space graphically, which is vital to every design student.

\subsection{Spatial visualization among multimedia students}

A person who is involved in the field of design, especially the 3D course, should be creative and innovative to transmit visuals and must have a high imagination to reflect 2D objects to 3D and vice versa. Lohman (1988) mentioned that spatial visualization is the ability to comprehend imaginary movements in a three-dimensional space or the ability to manipulate objects in imagination. According to Lowrie (2002), our society is becoming increasingly reliant on visual stimulus with new technologies pushing the boundaries between "real life" environments and two dimensional (2D) representations of three-dimensional (3D) space.

Besides that, according to Gutierrez (1996), 3D animation students should have perceptual constancy, i.e., the ability to recognize that some properties of an object are independent of size, color, texture, or position, and to remain unconfused when an object or picture is perceived in different orientations. Thus, imagination plays a vital role in sketching and designing a 3D model. Presmeg (1986) defined that dynamic visualization is the ability to reason the essential properties of moving, shrinking, and rotating figures, which appear on the screen or in their mind (Harel \& Sowder, 1998; Presmeg, 1986).

According to Workman and Lee (2004), the use of appropriate strategy will effectively enable the students to solve problems in design to develop their spatial visualization ability. With the help of 3D software, students can improve their spatial visualization skills. Additionally, Sorby and Baartmans (2003) mentioned that the use of multimedia with the workbook had shown a positive impact in developing and enhancing the three-dimensional spatial capabilities of the student.

Baum (1984) found that those who have high spatial skill levels are suitable for careers in the engineering field, architecture, design, mechanical, and mathematics. This shows that most design students have high spatial skill level regardless of conventional or digital approach. The approach of the traditional method in the learning process, students found it challenging to memorize and understand the process involved in spatial visualization. Thus they fail the task. Therefore, the heavy load of information in working memory will cause the failure of information to register in the long term memory during conduct that activity (Klein, 1996).

\subsection{Gender difference in spatial visualization}

There are many studies on gender differences in spatial visualization skills in various fields. Gender differences were prevalent among students who possess high spatial visualization ability, in favor of males. Males scored higher ratings in their spatial-imagery encoding and processing preferences than their verbal information processing preferences (Ramful \& Lowrie, 2016). According to Terlecki and Newcombe (2005), facilitation of computer experience through training may have differential effects on males and females' spatial abilities, and males not only perform at higher levels than females on tests of spatial and mental rotation abilities but also tend to have more spatial experiences.

There are considerable evidences pointing to the fact that boys and girls differ in their spatial abilities (Battista, 1990; Ben-Chaim, Lappan, \& Houang, 1988; McGuinness, 1993; Voyer et al., 1995). This tendency is equally observed in terms of spatial visualization (Mayer \& Massa, 2003). Different explanatory factors have been put forward to explain why boys and girls differ in spatial ability, recognizing the contribution of both learner related factors (such as cognitive variables) and environmental factors (such as activities in which boys and girls are engaged in their daily life). In terms of learnerrelated factors, substantial attention has focused on the ways in which boys and girls encode and process information, which is commonly referred to as cognitive style (Arnup, Murrihy, Roodenburg, McLean, 2013; Kozhevnikov, 2007; Mayer \& Massa, 2003).

Michael T. Battista (1990) suggested that whereas males and females differed in spatial visualization and theirperformance in high school geometry, they did not differ in logical reasoning ability or their use of geometric problemsolving strategies. Theories of these differences are related to a male sex hormone (Hier \& Crowley,1982), or the environmental factor is the main reason for male-female differences in spatial skill levels (Fennema \& Sherman, 1977). This is because males tend to look for a technique or method by using space and direction or orientation strategy, while 
females prefer to use sign and route directions (Lawton, 1994; Geary, 1998). The findings of this study are consistent with Koenig et al., (1990) that women's advantage is concerning to the absolute space (location of the object) while the male dominance is in the area coordinate relations (distance and direction).

Based on the existing Spatial Visualization test scores, gender differences in strategy has not been adopted widely, but at least one (Gluck \& Fitting, 2003) form that male more commonly used holistic approaches than female, and female more often used analytic and mixed strategies than male in two different spatial tests. The comprehensive plan relies on visualizing the whole object, and the analytic strategy uses a structured, stepwise approach. The holistic strategy has found to be most effective (i.e., less time consuming) in timed tests. Linn \& Peterson (1985) concluded that "spatial strategy selection" is a factor in gender differences in mental rotation tasks. However, Hsi et al. (1997) determined that visualization strategies can be acquired through training.

\subsection{Conclusion}

This study will establish on the relatively new issues of the possible relationship between 3D computer animation performance and Spatial Visualization for the computer graphics education in Malaysia. Literatures suggested that students with high spatial ability will likely perform better in the 3D computer animation course than students with low spatial knowledge. Spatial Visualization has a great potential to aid students in learning the complex tasks involved in the 3D computer animation performance. The 3D computer animation is a challenging course involving spatial task that requires substantial visualization ability, and not many multimedia undergraduates have the capabilities to handle this complicated visualization task. Spatial Ability, gender, and 3D Computer Animation performance can be used as a predictor to aid educators in designing the most suitable teaching materials for students with different levels of spatial visualization skills.

\section{Acknowledgments}

The authors gratefully acknowledge the Malaysian Government, Universiti Teknologi MARA (UiTM), and the Research Management Institute (RMI) under the Dana UCS (DUCS) grant and to those who participated directly or indirectly in this research project. Most profound appreciation to those who have assisted in the development and completion of this study.

\section{References}

A Battista, M. T. (1990) Spatial Visualization and Gender Differences in High School Geometry. Journal for Research in Mathematics Education

Christou, C., Jones, K., Pitta-Pantazi, D., Pittalis, M., Mousoulides, N., Matos, J.F., Sendova, E., Zachariades, T., \& Boytchev, P. (2007), Developing Student Spatial Ability with 3D Software Applications. Paper presented at the 5th Congress of the European Society for Research in Mathematics Education (CERME), Larnaca, Cyprus, 22-26 Feb 2007

Daniel B. Hier, M. D, and William F. Crowley, Jr. M. D, Spatial Ability in Androgen-Deficient Men (1982), The New England Journal of Medicine, 306:1202-1205, DOI: 10.1056/NEJM198205203062003

F. Mokhtar, S. Che Din (2013) Spatial Ability Test As A Predictor To Assess Students 3D Computer Animation Academic Performance Among University Undergraduates In Malaysia, Iceri2013 Proceedings, Pp. 4024-4032.

Gutierrez. S. Klein, (1996) Cognitive System-Principles of Leveling and Sharpening: Individual Differences in Visual Time- Error Assimilation Effects, Journal of Psychology, 37, 105-122

Judith Gluck and Sylvia Fitting, (2003) Spatial Strategy Selection: Interesting Incremental Information, International Journal of Testing, Volume 3, Issue 3 https://doi.org/10.1207/S15327574IJT0303_7

Harel, G., and Sowder, L. (1998), Student Proof Schemes Result from Exploratory Studies, in A. Schoenfeld, J. Kaput and E. Dubinsky (eds.), Research in Collegiate Mathematics III (pp. 234-282). American Mathematical Society.

I. M. Smith (1964) Spatial Ability: Its Educational and Social Significance, San Diego, CA: Robert R. Knapp

J. Pellegrino, D. Alderton, and V. Shute, (1984) Understanding Spatial Ability, Educational Psychologist.19(3):239-53

Kamis, Arasinah \& Mohamed, Suriani \& Hanapi, Zaliza \& Ghani, Che \& Che Kob, Che \& Jamaluddin, Rahimah. (2016). Fashion and clothing instrument for Malaysian fashion lecturers: An analysis of the instructors' competency scale. GEOGRAFIA OnlineTM Malaysian Journal of Society and Space 35 Themed issue on technological, vocational, and educational empowerment of Malaysia's human resource. 12. 35-45. 
Khoza, L. S., \& Workman, J. E. (2009) Effects of Culture and Training on Perceptual Learning Style and Spatial Task Performance in Apparel Design. Clothing \& Textiles Research Journal, 25(1), 62-79. DOI: 10.1177/0887302X07309635

Lohman, D. (1988), Spatial Abilities as Traits, Processes, and Knowledge, in R. J. Sternberg (ed.), Advances in the psychology of human intelligence (Vol. 4). Hillsdale, NJ: LEA.

Lowrie, T. (2002). The Influence of Visual and Spatial Reasoning in Interpreting Simulated 3D Worlds, International Journal of Computers in Mathematical Learning, 7(3), 301-318.

Mayer, R. E., \& Massa, L. J. (2003), Three Facets of Visual and Verbal Learners: Cognitive Ability, Cognitive Style, and Learning Preference. Journal of Educational Psychology, 95(4), 833-846. https://doi.org/10.1037/0022-0663.95.4.833

Michael T. Battista, Spatial Visualization and Gender Differences in High School Geometry, Journal for Research in Mathematics Education, Vol. 21 , No. 1 (Jan. 1990), pp. $47-60$

Mokhtar, H.S, A million clicks for Lee's parodies, News Straits Times Online, 22 August 2016, viewed 9 August 2018 < https://www.nst.com.my/news/2016/08/167404/million-clicks-lees- parodies>

Presmeg, N.: 1986), Visualization and Mathematical Giftedness, Educational Studies in Mathematics,17, 297- 311.

Ramful A., Lowrie T. (2016) Spatial Visualisation and Cognitive Style: How Do Gender Differences Play Out?

Sarah A. Burnett, David M. Lane, Lewis M. Dratt (1979) Spatial Visualization and Sex Differences in Quantitative Ability.

S. A. Sorby and B. J. Baartmans (1996), A Course for Development of 3D Spatial Visualization Skills, The Engineering Design Graphics Journal, vol.60, no.1, 13-20, 2003.

S. Baum (1984) Meeting the Needs of Learning Disabled Gifted Students, Roeper Review,7 (1), 36-19, 1984.

Strong, S., \& Smith, R. (2002). Spatial visualization: Fundamentals and trends in engineering graphics. Journal of Industrial Technology, 18(1), 1-5.

Workman, J. E. \& Lee, S-H. (2004) A Cross-Cultural Comparison of The Apparel Spatial Visualization Test and Paper Folding Test. Clothing and Textiles Research Journal, 22(1/2), 22-30. DOI: 10.1177/0887302X0402200104 